doi: 10.52370/TISC21214DL

\title{
HUMAN RESOURCE MANAGEMENT IN TOURISM DURING COVID-19 PANDEMIC
}

\author{
Dragana Lazićl ${ }^{\text {; Nedjo Danilović }}{ }^{2}$
}

\begin{abstract}
The subject of the paper is human resource management during the pandemic. The authors highlighted two issues: the influence of human resource management on business results in tourism and the impact of COVID-19 on labor law, psychological and interpersonal relationships in organizations dealing with tourism. The scientific goal is to confirm the hypothetical assumption that the COVID-19 pandemic limited and modified activities related to human resources management in tourism in emergency conditions. The paper uses the general scientific statistical and comparative method and method of document content analysis. The end effect of the work is two results: one, that COVID-19 affects the quality and quantity of human resource management in tourism, and the other, that the COVID-19 pandemic significantly reduces the satisfaction of basic tourism needs and requires the involvement of more institutions to preserve the satisfaction and safety of tourism employees and users of tourist services. The ultimate purpose of the paper is to harmonize the Labor Law regulations in the conditions of mass pandemics.
\end{abstract}

Key Words: Human resources, COVID-19, human resources management, tourism and labor law

JEL classification: J53

\section{Introduction}

The global pandemic caused by COVID-19 virus struck the Republic of Serbia in the spring of 2020. The first officially registered case of the virus

\footnotetext{
${ }^{1}$ Dragana Lazić, Assistant Professor, Faculty of Business and Law, MB University of Belgrade, +381640057422, dragana1908@yahoo.com

${ }^{2}$ Nedjo Danilović, Professor, Faculty of Business and Law, MB University of Belgrade, +38163241761, danilovic.nedjo@gmail.com
} 
infection on global scale was registered in China on 07 January 2020 (World Health Organization - WHO, 2020b). The first case in Europe was registered in France on 24 January 2020 (WHO, 2020a). The first infected individual in the Republic of Serbia in the city of Subotica was confirmed on 06 March 2020 (Ministry of Health of RS, 2020). Due to a high number of the infected and the inability to suppress this vicious disease more efficiently than it had been spreading, the World Health Organization declared the pandemic only five days following the discovery of the first case in the Republic of Serbia.

The severity of the situation worldwide and the necessity of applying drastic measures in our country was confirmed on 15 March 2020 when the Republic of Serbia declared the state of emergency (Decision on Declaring the State of Emergency in the Republic of Serbia, 2020). At the time of writing this paper (the beginning of 2021), according to the official statistics by the World Health Organization and the Ministry of Health of RS, 105,249,764 and 413,943 individuals were infected by this disease worldwide and in the Republic of Serbia, respectively. The number of the deceased is 2,298,606 and 4,168 worldwide and in the Republic of Serbia, respectively.

In the Republic of Serbia, since the official recognition of the virus as a dangerous 'invisible enemy', there have been numerous measures and restrictions, such as: national border closure, restrictions of movement and cancellation of public transport to reduce human contact, online schooling, closure of all stores (except foodstuff stores), online work instead of work in offices, closure of spa centers, swimming pools, gyms and other hotel facilities, which had negative effect on the development of hospitality and tourism. The abovementioned measures led to the decline in work load in a number of businesses, except those delivering medical services, or delivery services and online communication firms, and the likes. All of the above affected the employment, i.e. unemployment rate, working conditions, and, as a result, motivation to work, both worldwide and in our country and the region, in all industrial branches, especially tourism.

The International Labour Organization (ILO) estimates that the amount of working hours globally in the Q1 2020 decreased by 4.5\% which accounts for 130 million full-time workplace. The number of work hours in Q2 2020 is by $10.5 \%$ lower than in Q4 2019 prior to the crisis, which accounts for 305 million full-time work places (International Labour Organization, 2020). Undoubtedly, there is a significant impact of the global pandemic 
caused by COVID-19 virus on human resources and their engagement, and poses a great challenge for businesses in terms of good alignment between good business and protection of human resources, that is, their good management.

\section{Human Resource Management in Tourism}

The treatment of staff as the subjects rather than the objects of management is one of the notions of modern society whose needs and requirements are recognized by the concept of modern management, known as human resource management. The employees carry out their duties not only in terms of conducting their work-related activities and receiving suitable financial compensation, but also in terms of participating in the system of decision-making and management. Such an approach contributes to the better status of the employees within an organization and raising their morale.

Any changes in society, both planned and expected and those extraordinary due to great catastrophes and epidemics, have a strong impact on the system of human resource management. The process of creating, molding and affirming a new and improved system of human resources management is affected by a number of factors, such as faster scientific and technological development, tighter market competition, increased consumer demand, changes in lifestyle in general, and since recent times, a global pandemic caused by COVID-19 virus. The initiated processes are being continued, but how this will affect the future of the employers and the employees in all modern society sectors, including tourism, is yet to be seen.

\section{Activities of Human resources Management in Tourism}

Human resource management in tourism is conducted in the same manner as in other industrial branches. It entails a number of expert and professional activities that include: business analysis, planning, staff recruitment and selection, staff socialization and orientation, training and education, employee performance evaluation, rewards and incentives, health and safety, career management, employee demotion and dismissal. Good human resource management can be conducted only within the organization with labor division and specialization, and correlation between tourist organization resources, as well as adequate tourist organization coordination (Danilović \& Milosavljević, 2008, p. 105). 


\section{Job analysis}

Business analysis entails a critical review of constant changes in operations and conditions for their performance, especially as modern business requires a continuous acquisition of knowledge, capabilities, skills, and other employee potential. This results in the awareness of what and to what extent, or in which direction something needs to be changed. Business analysis can be defined as the process of constant and organized collecting, sorting and analyzing data and information on operations, required knowledge and skills, responsibilities, as well as other factors necessary for their performance (Jovanović et al., 2008).

Business analysis, as a human resource management activity comprises a number of actions with multiple effects for the benefit of an organization, such as: determining the requirements for operation performance, determining the necessary number of employees for each position, defining the relation between supervisors and subordinates, determining technical and other work-related requirements, re-defining the rules and principles of a reward system, etc. The process of the business analysis entails, among other things, the tasks, duties and responsibilities for each job, which obviously means that the business analysis findings are used in the process of jobs design as well (Milošević et al., 2012).

Business analysis is a human resource management activity which is also implemented in the field of tourism. Most of the business entities in the field of tourism compile documents on workplace organization and systematization containing precise information on the number of executives necessary for the uninterrupted operations, as well as detailed description of workplaces and all related duties. The Republic of Serbia is not behind the rest of the world and the region in regards to human resource management. The only problem with this type of human resource management is that a certain number of business entities still do not obtain a relevant bylaw on the job organization and systematization, which is something that needs to be attended in the future. The control of whether such documents exist or not, and their alignment with the current labour market changes and requirements should be performed more frequently and rigorously. The upgrade of job organization and systematization in the field of tourism would result in more detailed work division and elimination of double communication lines. There would also be a more clear line of responsibilities. 
Under the influence of the COVID-19 virus and changes in the work environment (taking over the work model from home, which is widely used in the world), it is expected that most organizations will accept telecommuting after the pandemic and change their way of functioning in accordance with the new situation. Acts on systematization and organization of jobs will need to be changed and adjusted to the conditions of the pandemic, entities in the tourism industry, realistic and feasible activities and possible methods of action of tourism entities, as well as the effects of the pandemic at the global, regional and national levels. According to the experience in tourism industry during global pandemic the process of adapting tourism to the newly-established methods of home working is demanding as certain hospitality activities and services, such as summer holidays on collective beaches, skiing in winter resorts, stay in spas, massages and other therapies, group recreational activities in gyms, etc., simply cannot be organized online.

\section{Human Resources Planning}

Human resources planning is an important management activity, which is why it is treated with great importance. Forecasts on human resources an organization requires, the definition of knowledge, capabilities and skills these human resources should obtain, and determination of staff fluctuations, are planned activities. Human resource planning is a scheduled process where human resources are well planned in advance, and where a strategy for their provision is prepared (Slavković, 2004). The unexpected global pandemics render human resources planning in tourism even more significant.

We are aware that human resource planning in most of the organizations running their business in Serbia, and whose core business is tourism, is not on high level. Thus, the performance of such activities should be aligned with the practice in more developed countries. For example, in developed countries (such as Germany) work-related training for certain jobs within organizations is always conducted for more trainees than necessary, as it is assumed that a certain number of trainees is going to resign, leave to another organization or terminate their work for some other reason. If any of the above reasons is not in case, the 'surplus' of trainees is to be prequalified for another job. This results in staff with multiple knowledge in different areas of work within the organization, and with the ability to perform more jobs, or the ability to handle job rotations and similar situations in a better way. This also results in human resource development, 
which is a main potential in any organization. On the other hand, in the Republic of Serbia, there is usually one executive for one workplace, and in case they leave an organization, their work will be carried out by their co-workers who are not trained for it, or this job is 'pending', which leads to lower efficiency at work.

\section{Recruitment}

Human resource recruitment in tourism is a two-way process, with an organization requiring new staff to fill up vacancies on one end, and a candidate interested in starting new employment on the other. This is the process where an organization must make effort to select the best candidates, that is, the candidates with the best references. On the other hand, a candidate must take into account the acceptability of the potential employment.

Job recruitment process can be conducted internally (within the organization) or externally (outside the organization). The advantages of internal recruitment process are considered to be: awareness of positive and negative features of candidates, creation of circumstances for good candidates to develop, positive effect on the morale and motivation among the employees, faster and more efficient staff recruitment, etc. The disadvantages of such staff recruitment process is a possibility of internal tensions and hostility due to different opinion on potential candidates for promotion, resistance to changes and so on. If we know that new people bring new ideas, lower internal tensions, and raise the potential for better selection of the staff, it is not difficult to conclude that the advantages of external recruitment process must always be taken into consideration. According to the above, it can be concluded that the most favorable process is the combination of the internal and external recruitment process.

In the developed countries (Germany) the staff recruitment and selection process is mostly conducted by headhunting agencies. In the Republic of Serbia, on the other hand, this process is mostly conducted by the employers. This has not been proven as very efficient, especially in terms of the absence of several levels of interviewing and testing for the applicants. Candidate selection which is based only on one criterion, a single interview or test, turned out to be insufficient. Such circumstances mean that neither the employer can have the adequate impression of the candidate, nor the candidates can present all their qualities. This is the reason why candidate selection should be conducted by professionals based 
on the applicants' criteria the organization aims to obtain. This reduces the likelihood of nepotism (Danilović \& Lazić, 2019), since the organization has no information on the applicants (it has only the information on the criteria they need to meet), and the applicants have no information on their potential employer, but are aware of the requirements they need to fulfill. This would also reduce trading in influence in the employment process, which is seen as a great problem in any area in the Republic of Serbia, including tourism (Danilović \& Lazić, 2020). In case of tourism, this is even more present due to the increased recruitments of candidates for seasonal tourism activities.

\section{Staff Socialization and Orientation}

Staff socialization and orientation mean acquaintance of the newlyemployed with the job to be performed, their rights and obligations, future colleagues and the code of conduct within the organization. The main objective of staff socialization and orientation is to reduce staff fluctuation, increase interpersonal acceptance, and establishment of positive impression on the organization (Ratković-Njegovan \& Vukadinović, 2011).

Stress reduction and facilitation of the acceptance of the newly employed results in humanization of the employment, which is actually another objective of staff socialization and orientation. Educating new employees for the independent and productive work in tourism, acquaintance with the culture, circumstances and development plans in the organization entails the activities conducted for the purpose of good orientation of the newly employed.

Interpersonal relations are important for good functioning of the tourist organizations. In the developed countries (Germany, for example) the organizations have already been arranging, at least once or twice a year the activities for staff to socialize, acquaint and familiarize with each other. For example, the teambuilding activities have been conducted for a long time in the organizations taking care of their staff socialization and orientation. Such practice is yet to be introduced in the Republic of Serbia. In addition to these activities, celebrations of anniversaries, achieved results, or some other important dates (New Year, Women's Day, etc.) are good examples of the investment in the improvement of the interpersonal relations. 
Holidays are an excellent opportunity to show the employees how their organization appreciates them and how their employer takes care of them and their families. More developed business entities often have their own accommodation in resorts, mountains, spas, which enables them to once or twice a year enable their employees and their families to use this accommodation. As an example, ski resorts of Serbia provide their employees with the accommodation in the mountains during the winter season, and, thus, show their care for the employees, and support the development of tourism.

\section{Staff Training, Professional Education and Development}

Due to the increasing influence of training and professional education of the employees of the organizational and individual success, but also due to continuous technological development of the organization with tourism as core business, there are more and more organizations that choose to arrange for courses, training and professional education and development of their employees.

Scheduled and organized practice and development of different activities necessary for better job performance entail training courses and drilling of the employees. This is seen as a possibility for the employers to invest in their staff and their potential. The content of any training is usually determined by the employees within the human resource service, while the decision on the venue of the training is made by senior management. Unfulfilled work standards and poor performance at work are the best indicators of the necessity to organize training for the staff. Staff training can be organized as individual guidance, job rotation, internship, tutoring, corporate training (fellowship and placement). External training, however, burdens an organization with additional expenses, the most common being: conferences, lectures, programmed learning, simulations, etc.

Most of the tourist organizations in Serbia send their employees on professional training courses. However, there is still a small number organizations that do not allocate finances for such human resource management. Therefore, there is a need to have a constant raise in the awareness of the advantages of the investment into the knowledge and development of the employees that are considered to be the greatest asset of the 21st century. In circumstances when all tourist organizations were affected by COVID-19 pandemic, no one can expect significant finances to be allocated for staff development, especially having in mind the severity 
of the circumstances. Due to numerous expenses resulting from COVID19 pandemic, many tourist organizations are struggling to remain liquid, to run their business with minimum loss, even though this stage of human resources management suffers the most.

\section{Employee Performance Evaluation}

The measurement and evaluation of operational results of the employees in tourism is often defined as the evaluation of their performance. The evaluation of the employees' operational results is often taken as the basis of their rewards and incentives. The subject of operational results evaluation is: familiarity with one's job, quality and quantity of work, reliability, responsibility and relations with one's colleagues and clients.

In order to achieve a satisfying evaluation of the conducted process, the managers should have a personal file for each employee where they can enter data on their responsibility, knowledge, skills, discipline, as well as on their remarks on an employee's work-related results. In order to inform the employees on the rating of their work, the managers are to arrange a meeting with them. This meeting should serve to acquaint an employee with their results and areas where there is a possibility for the improvement.

The evaluation of the employee performance and development in tourism has long been recognized as a good practice in the developed countries. As opposed to most of the organizations running their business in the Republic of Serbia, the managers in the developed countries, at least once a year, conduct so-called 'annual interviews' where they give marks 1 to 5 to $t$ them their employees' engagement, and present them with the reasoning for their mark. If an employee's mark is closer to 1 , he or she will have a number of sanctions, a warning, or a training to improve the lacking knowledge or skills. On the other hand, if this mark is closer to 5, such employee an expect a number of benefits, such as promotion, financial reward, etc. Unfortunately, the practice in the Republic of Serbia is such that the evaluation of the employees' performance and development is conducted only in the organizations owned by foreigners from developed countries. Good performance by the employees in tourism depends not lonely on themselves but numerous external factors. Notwithstanding the great ill and wish to work, or the effort they make, the work performance by most of the employees in the field of tourism was absent during COVID19 pandemic. The reasons probably lie in the inability to deliver tourist 
services due to shortage of potential clients, restrictions in movement and gatherings in the tourist facilities or tourist destinations.

\section{Staff Rewards and Incentives}

The system of rewards and incentives for the employees is the most complex and most delicate function in the field of human resources management. It comprises earnings, salaries and other income of the employees as material rewards and compensations on one hand, and their immaterial rewards and incentive strategies on the other. Apart from their earnings, that is salaries, the employees are entitled to other benefits based on their work and employment: meal allowances, travel expenses allowance, movement allowance, vacation allowance, severance pay, damages due to injuries at work, etc. In addition, the employees are entitled to contributions based on their pension, disability and health insurance, as well as the contributions in case of temporary unemployment, which are paid by the employer to special funds in line with the applicable regulations. Periodic shifts from one assignment to another as a manner to reduce monotony at work is used as an employees' immaterial incentive. Such approach is mostly defined as job rotation.

Inclusion of the employees in the decision-making process, especially those decisions concerning the strategic issues within the organization is an example of the employee participation in the management, and is considered as one of the most important motivation methods. Flexible working hours is another significant immaterial incentive strategy for the employees. It implies a possibility to organize one's working hours on daily, weekly, annual, and sometimes, multi-annual level. Despite certain shortcomings, there are numerous benefits attached to flexible working hours. The Foreign Investors Council concluded in their White Book for 2020 that further reform of the Labour Law should prioritize 'the need for recognizing and arranging for more flexible forms of work, such as home working' (Foreign Investors Council, 2020).

Having in mind all the above ways to motivate the employees, it has been concluded that the amount and regularity of remuneration has the biggest impact on the employees' satisfaction or dissatisfaction. Without any need to make comparisons with the countries in the region, we can conclude that this segment of human resources management and the employees' motivation is the most problematic in the Republic of Serbia. A great number of people in Serbia has a problem with the payment of their 
remuneration based on their work. There are still employers that do not remunerate their employees in timely manner, and despite the amendments in the applicable regulations, this issue remains to be outstanding. There are irresponsible employers that had found the way to pay out their employees' salaries, but not other contributions based on health and pension insurance, etc. This is the reason for the most of the complaints to labour inspections. According to the Inspection Oversight Plan of the Labour Inspectorate for 2020, each labour inspector is intended to conduct at least 150 inspection oversight instances, which is less in comparison with the number in 2019 when each inspector was intended to conduct 170 inspection oversights. This is yet another negative remark to the Republic of Serbia on its labour regulations. Therefore, the solution to this problem is still far, as, instead of applying stricter control, the Republic of Serbia is confronted with the lack of staff in the field of inspection.

There were no material rewards for the employees during COVID-19 pandemic, and the organizations resorted only to immaterial types of rewards. Tourist organizations and other business entities closely linked with the field of tourism are facing great financial challenges, and, thus, it is unrealistic to expect them to obtain any surplus in finances that could be redirected to reward system.

\section{Health Protection and Safety at Work}

The system of staff health protection is regulated by the Labour Law of the Republic of Serbia of 2018, and the Law on Safety and Health at Work of the Republic of Serbia of 2017. Modern organizations invest a great deal of resources and effort in order to raise the awareness of their employees of the need to protect their safety and health at work. As a result, these organizations often arrange for programs promoting good health among the employees. This also implies additional protection for special categories of people, such as youth, pregnant women, women in labour, disabled employees, people with special needs, people with health issues and so on.

The minors in the Republic of Serbia are not allowed to be engaged in fulltime employment, to work at night, overtime, or conduct activities that could have adverse effect on their further psychical and psychological development, etc. Among other things, this means that they are protected from any physical work that is conducted under ground or water, on high altitude, or in the environment where they are exposed to harmful radiation, etc. Although the work of minors is protected by law, we are aware that 
this is not paralleled in practice. Pregnant women and women in labour also have special protection at work. According to the Labour Law, pregnant women cannot conduct activities that require heavy lifting, exposure to harmful radiation, or extremely high or low temperatures. Unlike pregnant women, the protection of women in labour is established as the protection of a woman and an infant. However, it is a well-known fact that women who are planning to start a family have more difficulties in securing employment, or that pregnant women are often dismissed from work. The regulations governing this area in RS is in line with those in the developed countries, and even better in certain segments as maternity leave intended for a child care is much longer in Serbia than some other countries. However, there is still a problem of the implementation and putting these regulations into effect.

The Labour Law places special attention to one more category - disabled workers, that is, individuals whose health and fitness have been permanently impaired or reduced due to work they had conducted. The employer is required to ensure these workers continue to carry out jobs in line with their remaining abilities. However, once again, we can see that this is not a part of practice in RS. This segment of human resources management has gained particular significance during global COVID-19 pandemic. The health and health care of the citizens, and especially employees have become a priority, so that the state and the business entities allocate significant financial resources to encourage economy, social benefits and regular provision of the citizens with basic needs, staff testing, provision of means of disinfection and disinfection chambers at the entrances to and exits from living and working premises, organization of home working in multiple shifts, provision of protection means and so on. All of the above measures by the state and business entities undoubtedly show how much they care for the health of their citizens and employees. In case of tourism, in addition to employee protection, it is necessary to provide for the protection of all guests and visitors, which requires great financial resources.

\section{Career Development, Demotion and Dismissal}

Career development, demotion and dismissal are considered to be the final activities in human resource management. The choice of the appropriate job and becoming a part of an organization is the onset of one's career establishment. The initial phase in career establishment is considered as rather stressful for the newly-employed, since this is the phase of adapting 
to new working environment and a new organization. The next stage is the stage of career development and is marked by career progress. The third stage is from between 40 and 45 to between 50 and 55 years of age. In this stage, one's career is kept at satisfying level, which is why this is marked as career maintenance. As a rule the employees in this stage feel a high level of attachment to their organization, and as a result, identify their personal goals with the goals of the organization. The individual and professional development is finalized by gradual withdrawal and decrease in the activities, which is why this stage is often marked as the stage of late career. This is the phase when the senior employees pass their knowledge and lessons learned on their younger colleagues and prepare for the retirement.

The loss of position within the organization, that is, the shift of the employees from higher to lower and less paid workplaces represent the employees demotion (Lojić et al., 2011). Demotion is usually caused by unconscientious and undisciplined conduct at work, poor performance, or lack of required knowledge, skills or qualifications. The employees are dismissed only if there are substantiated reasons leading to this. For example, in case of severe breach of work-related duties, grave impairment of work and technological discipline, frequent conflict behavior at work, etc.

This stage of human resource management is also marked by numerous irregularities. Termination of employment, in addition to being one of the most stressful experiences for an employee, is also a turning point when employees realize that, in the state governed by the rule of law, they cannot exercise their vested rights, or they exercise them partially, with many obstacles. Therefore, the regulatory framework is in place. In terms of the employees career management, it is harmonized with the regulatory framework of the developed countries. However, there are problems in in implementing these regulations which is not in line with the level of social awareness development, and results from underdeveloped 'legal state' and its higher quality, 'the rule of law'. This is substantiated by a number of instances of unpaid salaries and employment contributions, as well as inappropriate wording at the time of one's dismissal and demotion.

The employees in the sector of tourism during COVID-19 pandemic have often been confronted with the termination of their employment or nonextension of their employment contract due to financial losses made by tourist organizations. Unfortunately, there is no precise statistics in the 
Republic of Serbia on the number of employees in tourism who have been dismissed during COVID-19 pandemic. It is only known that 800 employees in tourist agencies have lost their jobs. At the same time, it assumed that this number is much higher since lower number of tourist arrangements and their users radically diminishes workload of tourist organizations, and, thus, the demand for relevant workforce.

\section{COVID-19, Workforce and Tourism in the Republic of Serbia}

From an epistemological point of view, the previous year (2020) was extremely difficult for the sector of tourism in the Republic of Serbia and the other countries in the region, but the world as well. Global pandemic due to COVID-19 virus disrupted various spheres of life (health system, schooling, culture), but it seems tourism has been struck the most. Scientific analyses conducted so far point at detrimental economic, health and social effects of the pandemic. Truth be told, currently, these cannot be foreseen entirely, but the perceived tendencies and trends show that the impact of global pandemic is to be larger than expected.

Following the example of other countries affected by the pandemic, the Republic of Serbia tackled numerous challenges stemming from the global pandemic in a systematic and responsible manner. In addition, according to the exact statistical indicators (data from the Republic Bureau of Statistics of the Republic of Serbia), it can be concluded that, in certain fields of combat against COVID-19, Serbia has shown great determination, persistence and success (many forms of economic assistance, financial assistance to citizens) while in the others, powerlessness and disorganization (weakness of the health system).

A number of international organizations joined the struggle with COVID19 pandemic. For the purpose of this paper, it is important to underline that many of these organizations manage the situation badly. Notwithstanding numerous examples of bad management by the highest bodies of the European Union, it is worthy of praise that the European Commission, instead of austerity measures (introduced during 2008 global economic crisis), this time it opted for economic investments. Owing to the measures taken by the European Union, there was an abundant package of financial assistance to the Member States amounting to 750 bn euros, with special packages aimed at the preservation of the employees and their jobs, such as SURE programme, worth 100 bn euros ensuring loans for sustaining employment. The European Union approved a similar assistance package 
for the countries of the Western Balkans as well, which, among other things, enabled widening and reinforcement of the Youth Guarantee scheme in the countries in the region (European Commission, 2020b).

It is important to underline that the pandemic caused by COVID-19 virus led to radical deterioration of labour rights, both worldwide and in Serbia. The EC in its report for 2020 repeated its estimate from the previous report for the Republic of Serbia that the Labour Law is only partially aligned with the EU acquis and that it needs to be further amended (European Commission, 2020a).

The state of the emergency led to a substantial decline in the labour rights in the Republic of Serbia in all areas of tourism industry. According to YUTA statistics, the loss in tourism due to pandemic will have a 50 million euros loss as a consequence. On the other hand, the World Tourism Organization reported such losses on global scale being between 300 and 450 bn euros. The above meant finding new ways of promoting domestic tourism and attracting domestic tourist to visit their own country and see its beauties, but in epidemiologically safe manner, with as high comfort and service quality as reasonably achievable. All of these requirements put before tourist organizations needed to be met with as low financial resources as possible and reduced workforce (both due to virus infection and financial issues).

In 2020, the overall number of tourist visits in the Republic of Serbia was $1,820,021$ (decline by $50,7 \%$ in comparison with 2019 , with $1,374,310$ being domestic tourists - decline by $25.4 \%$ ). The number of foreign tourists was 445,711 (decline by $75.9 \%$ in comparison with 2019). In 2020, there were 6,201,290 instances of overnight stay (decline by $38,4 \%$ in comparison with 2019), with 4,936,732 being by domestic tourists (decline by $18.6 \%$ in comparison with 2019). It needs to be noted that in 2020 most of these visits $(51,459)$ and overnight stays $(128,020)$ were by the tourists from Bosnia and Herzegovina. All the above data lead to a conclusion that COVID-19 had an enormous impact on global, European and domestic tourism, and that tourist industry will require a long period to recover.

\section{Conclusion}

In the Republic of Serbia, for the past year of struggling with COVID-19, human resources management has been completely suppressed in a number of segments and the issue of employment, that is unemployment has been 
prioritized. Hence, the fundamental human and existential needs have been compromised, which means that the struggle to ensure the minimum of resources for a family or a household has become a priority, and the need to maintain and increase work-related morale has been put aside, which, in case COVID-19 pandemic prolongs, could have unprecedented consequences.

Many people have been affected by this virus and the measures taken by states to combat the pandemic, and a large number of people have lost their jobs. The causes of the employees dismissal in almost all the countries are almost the same. The most common reasons for dismissals in the sector of tourism are the fact that the organizations fully discontinued their activities and inability to prolong temporary employment contracts. In addition, dismissals were also prompted by the employees' inability to go to work due to restrictions in public transport, or inability to organize care for children when most of the kindergartens and schools were closed. The highest percentage of dismissals were in certain branches of industry such as tourism, trade and processing industry.

COVID-19 pandemic had impact not only on the (un)employment rate, but also led to significant changes in the organization of work, work premises, and working conditions for the employees in the Republic of Serbia. Most of these changes were connected with the organization of home working (which is in case of tourism unfavorable solution, and in most of the cases impossible to implement), and reduced working hours or number of shifts. It has to be noted that a number of men and women used the possibility of involuntary annual leave, reductions in salary or overtime work, as well as the option of having one's work temporarily suspended.

In conclusion, it can be stated that the Republic of Serbia has a good legal grounds to regulate employment, but it needs to be slightly corrected and amended in line with the legislation in the developed countries. The outstanding issues remain in the field of implementation, which in its essence a sign of insufficiencies in terms of the rule of law. Thus, the institutional framework not organized in a systematic way, unattended reforms of business and social systems being partially sluggish and outdated and requiring swift reforms, are the main problems that need to be attended. 


\section{References}

1. Danilović, N., Lazić, D. (2019). Corruption and corruption offences in tourism. TISC - Tourism International Scientific Conference, Vrnjačka Banja, 4(1), 663-681.

2. Danilović, N., Lazić, D. (2020). Forest devastation and illegal logging impediment to development of tourism. TISC - Tourism International Scientific Conference, Vrnjačka Banja, 5(2), 112-129.

3. Danilović, N., Milosavljević, S. (2008). Osnovi bezbednosne analitike, Službeni glasnik, Beograd.

4. Decision on Declaring the State of Emergency in RS, (2020), https://www.propisi.net/odluka-o-proglasenju-vanrednogstanja/, January 2021).

5. European Commission, (2020a), Commission Staff Working Document - Serbia (2020) Report - Accompanying the Communication from the Commission to the European Parliament, the Council, the European Economic and Social Committee and the Committee of the Regions, 2020 Communication on EU Enlargement Policy, https://ec.europa.eu/ neighbourhood-enlargement/sites/near/files/serbia_report_2020.pdf, (14 January 2021).

6. European Commission, (2020b), Communication from the Commission to the European Parliament, the Council, the European Economic and Social Committee and the Committee of the Regions - An Economic and Investment Plan for the Western Balkans, https://ec.europa.eu/ neighbourhood-enlargement/sites/near/files/communication_on_wb_ economic_and_investment_plan_october_2020_en.pdf, (14 January 2021).

7. Foreign Investor Council, (2020), White Book - Recommendations for better business environment in Serbia, https://fic.org.rs/wp-content/ uploads/2020/11/White-Book-2020.pdf, (14 January 2021).

8. International Labour Organization, (2020), https://www.ilo.org/ global/statistics-and-databases/lang--en/index.htm, (25 January 2021). 
9. Jovanović, M., Kulić, Ž., Cvetkovski, T. (2008). Osnovi upravljanja ljudskim resursima, Univerzitet Megatrend, Beograd.

10. Lojić, R., Igov, D., Kankaraš, M. (2011). Lojić, R., Igov, D., Kankaraš, M. (2011). Upravljanje ljudskim resursima u sistemu odbrane kao predmetno područje menadžmenta ljudskih resursa. Vojno delo, Vol. 63, No. 2, 273-285.

11. Milošević, G., Kulić, Ž., Nikač, Ž. (2012). Analiza posla kao deo aktivnosti u oblasti upravljanja ljudskim resursima, Hrvatsko udruženje inženjera sigurnosti, Zagreb.

12. Ministry of Health of RS, (2020), https://covid19.rs, (25 January 2021).

13. Ratković-Njegovan, B., Vukadinović, M. (2011). Sadržaj i efekti organizacione socijalizacije u poslovnim integracijama. Škola biznisa, No. 3, 102-115.

14. Slavković, M. (2004). Planiranje ljudskih resursa, Horizont fondacija, Banja Luka.

15. World Health Organization - WHO, (2020a), 2019-nCoV outbreak: first cases confirmed in Europe, http://www.euro.who.int/en/healthtopics/health-emergencies/coronavirus-covid-19/news/news/2020/01/ 2019-ncovoutbreak-first-cases-confirmed-in-europe, (25 January 2021).

16. World Health Organization - WHO, (2020b), Coronavirus disease (COVID-19) outbreak, http://www.euro.who.int/en/health-topics/healthemergencies/coronavirus-covid-19/novel-coronavirus-2019-ncov, January 2021). 